\title{
Science, Art and Sports School at Sinop Children's University: Its Effects on Children's Perceptions
}

\author{
Hüseyin Eş \\ Sinop University, Faculty of Education, Sinop, Turkey, huseyines@ sinop.edu.tr \\ Nurhan Öztürk Geren \\ Sinop University, Faculty of Education, Sinop, Turkey, nurhanozturk41 @gmail.com \\ Esra Bozkurt Altan \\ Sinop University, Faculty of Education, Sinop, Turkey, bzkrt.esra@ gmail.com
}

\begin{abstract}
The purpose of the present study is to evaluate the children's perceptions about the Entertaining Science, Art and Sports School at Sinop Children's University, which is a project including various science, art and sports activities carried out at Children's University of Sinop University. All the processes of the study from data collection to data analysis were conducted through qualitative research paradigm. The data of the study were collected by means of poster and interview techniques. The study group consists of 50 students finishing 5th grade in 20122013 school year and participating in the above-mentioned project. During the project lasting for 5 days, 23 different science, art and sports activities were performed; yet, most of the activities were science activities. At the end of the fifth day, the students were asked to prepare a poster by reflecting on the experiences they had during the activities of the project and then the students were asked what they wanted to depict in their posters through semi-structured interviews. The study concluded that the students liked all the activities conducted during the project but they liked most the activities in which they actively participated.
\end{abstract}

Keywords Children's university, science camp, science school.

\section{Öğrencilerde Bıraktığı Etkilerle Sinop Çocuk Üniversitesi’nde Bilim, Sanat ve Spor Okulu}

ÖZ Bu araştırmada, Sinop Üniversitesi Çocuk Üniversitesi’nde gerçekleştirilen çeşitli bilim, sanat ve spor etkinliklerini içeren bir proje olan Sinop Çocuk Üniversitesi'nde Eğlenceli Bilim, Sanat ve Spor Okulu'nu öğrenci görüşleriyle değerlendirmek amaçlanmıştır. Araştırmanın veri toplamadan veri analizine tüm süreci nitel araştırma paradigması ile yürütülmüştür. Araştırmanın çalışma grubunu söz konusu projeye katılan ve 2012-2013 eğitim-öğretim yılında 5. sınıfı bitirerek 6. sınıfa geçmiş olan 50 öğrenci oluşturmaktadır. Araştırmanın verileri poster ve görüşme tekniği kullanarak toplanmıştır. Beş gün süren projede süreç boyunca ağırlıklı olarak bilim olmak üzere toplam 23 farklı, bilim, sanat ve spor etkinliği gerçekleştirilmiştir. Beşinci günün sonunda öğrencilerden projede gerçekleştirdikleri etkinlikleri düşünerek beş günlük süreci yanıştan poster hazırlamaları istenmiş, ardından öğrencilere posterlerinde neleri anlatmak istedikleri yarı yapılandırılmış görüşmeler ile sorulmuştur. Posterlere ilişkin veriler betimsel analiz ile öğrenciler ile yapılan yarı-yapılandırılmış görüşmeler ise içerik analizi ile çözümlenmiştir. Araştırmada öğrencilerin proje süresince tüm etkinlikleri sevdikleri ancak en çok etkilendikleri etkinliklerin kendilerinin aktif olarak yer aldıkları etkinlikler olduğu belirlenmiştir. Ayrıca, öğrencilerin süreçte eğlenerek ve yaparken öğrendiklerine, sanat ve spor etkinliklerinin de süreçte yer almasını olumlu bulduklarına vurgu yaptıkları tespit edilmiştir.

Anahtar Çocuk üniversitesi, bilim kampı, bilim okulu. 


\section{GENIŞLETILMIŞ ÖZET}

Fen ile günlük yaşam arasında ilişki kurabilen ve öğrendiklerini günlük yaşamla ilişkilendirebilen fen okuryazarı bireylerin geliştirilmesinde formal eğitimin yanında informal fen eğitimi de önemli bir yer tutmaktadır (Stocklmayer \& Gilbert, 2003). İnformal ortamlar, çocukların okullarda öğrendikleri bilgi ve becerileri tamamlama, araştırma ve deney yapmayı mümkün kılma ve bilgiye ulaşmak için sorgulayıcı ve çok yönlü düşünmelerine katkı sağlama bakımından etkili ortamlardır (Noel-Storr, 2004). Diğer bir deyişle informal ortamlarda yapılan eğitimler, okullarda yapılan formal eğitimlerle kazandırılması güç olan, ilk elden gözlem yapma firsatı sağlaması açısından sınıf içi etkinlikleri tamamlayıcı bir etkiye sahiptir (Emmons, 1997). Bu ortamlarda, öğrencilere geniş zaman sunulmasından dolayı öğrencilerin bilgilerini en iyi şekilde yapılandırmaları beklenmektedir (Melber \& Abraham, 1999). Bu bağlamda bilim kampları, öğrenme ortamı öğrencileri motive edici olan ve ilgi çekici, öğrencilerin keşfetmelerine, gözlem yapmalarına, yaptıkları gözlemleri sıralamalarına ve gözlemlerden çıkarımlar yapmalarına firsatlar sunan informal ortamlardır. İnformal eğitim ortamları uzun yıllardır fen eğitiminde etkin bir şekilde kullanılıyor olmakla birlikte son yıllarda bu ortamlar çocuklara birçok disipline yönelik uygulamalı eğitim sunan "Çocuk Üniversitesi” adıyla kurumsal bir kimlik kazanma eğilimindedir. Çocuk Üniversitelerinin kurulmasının altında yatan nedenler, çocukların fen alanında eleştirel düşünmeleri ve merak duygusu kazanma noktasında onları cesaretlendirmek, onların üniversite ile tanışmalarını sağlayarak akademik kültürlerine 1şık tutmak ve gelecekte yapacakları tercihlere yol göstermek olarak ifade edilebilir (EUCU, 2013). Bu amaçlara hizmet eden Çocuk Üniversitelerinin dünyada olduğu gibi Türkiye'de de hızla yaygınlaşmasının ve buralarda gerçekleştirilen etkinlikler ile çocukların bilim ve bilimsel faaliyetlerle erken yaşlarda tanışmalarında büyük öneme sahip olduğu düşünülmektedir.

Bu araştırmada, TÜBITTAK desteğiyle gerçekleştirilmiş olan "Sinop Çocuk Üniversitesi'nde Eğlenceli Bilim, Sanat ve Spor Okulu"'nda yapılan öğretim etkinliklerinin ayrıntılı bir şekilde sunulması ve öğrencilerin yapılan etkinliklerle ilgili olarak hazırladıkları posterlerin değerlendirilmesi ve bu şekilde etkinliklerin öğrencilerde bıraktığı etkilerin tespit edilmesi amaçlanmıştır.

Araştırmada, nitel araştırma metodolojisinin desenlerinden biri olan, bir ya da birkaç özel durumu çok yönlü, sistemli ve derinlemesine inceleyerek analiz edilmesini sağlayan durum çalışması (case study) yöntemi (Yıldırım \& Şimşek, 2008) kullanılmıştır. Araştırmanın çalışma grubunu, Sinop ili Merkez İlçesinde ve merkez köylerinde bulunan ilköğretim okullarının 5 .sınıfını bitirmiş 6 .sınıfa geçmiş 50 öğrenci oluşturmaktadır. Gönüllü öğrencilerin başvuruları, başvuru formu ve istenen ekleriyle birlikte belirlenen tarihler arasında alınmış ve katılımcılar, yapılan başvurular arasından basit tesadüfí örnekleme yöntemi ile belirlenmiştir.

TÜBİTAK desteğiyle Sinop Üniversitesi Çocuk Üniversitesi tarafından gerçekleştirilen "Sinop Çocuk Üniversitesi'nde Ĕglenceli Bilim, Sanat ve Spor Okulu" adlı projede 1 yürütücü, 5 uzman, 12 eğitmen, 10 rehber ve 1 birim sekreteri olmak üzere toplam 29 personel görev almıştır. Projede 5 gün boyunca büyük çoğunluğu bilim ile ilgili olmak üzere 22 farklı bilim, sanat ve spor etkinliğgi gerçekleştirilmiştir. $\mathrm{Bu}$ etkinliklerin öğrencilerin ilgisini çeken, gündelik yaşamla ilişkili olan ve kolay ulaşılabilir malzemelerle yapılabilmesine ve süreç sonunda bireylerin de kolaylıkla yapabilecekleri etkinlikler olmasına özen gösterilmiştir.

Araştırmanın veri kaynağını, projenin son günü gerçekleştirilen "Poster Yarışması: Hayal Gücümüz İş Başında" adlı etkinlikte hazırlanan posterler ve ardından öğrencilerin posterlerine yönelik yaptıkları açıklamalar oluşturmaktadır. Bu etkinlikte öğrencilerden proje süresi boyunca yaptıkları etkinlikleri düşünerek bu projeyi hiç bilmeyen birine anlatmak isteseler nasıl anlatabileceklerini düşünmeleri ve bu doğrultuda poster hazırlamaları istenmiştir. Her öğrencinin bireysel olarak poster hazırladığı bu etkinlikte posterlerini hazırlamaları için öğrencilere 60 dakika süre verilmiş Öğrencilerin posterleri toplanarak araştırmacılar tarafindan ön inceleme yapılmış ve panolarda sergilenmiştir. Tüm öğrenciler önce 10 dakika kadar tüm sergiyi dolaşmışlar ve her posteri inceleme firsatı bulmuşlardır. Ardından her öğrenci kendi posterinde neler yaptı̆̆ını, çizdiği resimlerde neyi anlatmak istediğini, yazdığı yazılarla karşısındakine ne gibi mesajlar vermek istediğini açıklamış ve bu süreç kamera ile kayıt altına alınmıştır. Nitel veri analizinin kullanıldığı bu araştırmadan elde edilen veriler iki şekilde değerlendirilmiştir. Verilerin analizinde NVivo 8 Nitel Veri Analiz Programı kullanılmış ve verilerin bir kısmı betimsel analize, bir kısmı ise içerik analizine tabii tutulmuştur. Değerlendirmenin ilk basamağında, öğrencilerin posterlerinde en çok sevdikleri ve etkilendikleri etkinlikler belirlenmiştir. Öğrencilerin bahsettiği her bir 
etkinlik bir tema olarak belirlenmiş ve bu bağlamda betimsel analize başvurulmuştur. Değerlendirmenin ikinci basamağında ise öğrencilerin posterleri ile ilgili belirttikleri görüşleri oluşturmaktadır. Bilim, sanat ve spor okulu sürecinin sonunda öğrencilerin proje ve projede yer alan etkinliklerle ilgili olarak belirttikleri görüşler incelenerek, kodlama anahtarı oluşturulmuş ve verileri "içerik analizi"yle çözümlenmiştir. Kodlama anahtarının oluşturulmasında NVivo8 Nitel veri analiz programı kullanılmıştır.

Araştırma bulguları dikkate alındığında öğrencilerin posterlerinde kendilerinin daha aktif yer aldığı etkinliklerden bahsettikleri düşünülmektedir. Zira öğrencilerin posterlerinde en çok yer verdikleri etkinliklerin sevdikleri, eğlendikleri ve etkilendikleri etkinlikler olduğu belirlenmiştir. Bununla birlikte posterlerle ilgili görüşlerinde öğrencilerin büyük bir kısmı, çocuk üniversitesinde yapılan etkinlikleri çok sevdiklerini, bilim etkinlikleriyle birlikte sanat ve spor etkinliklerinin de yer almasının daha motive edici olduğunu, bazı etkinliklerle ilk kez karşılaştıklarını, ilk kez yapma fırsatı yakaladıklarını, yaparken öğrendiklerini hissettiklerini ve öğrendikleri bilgileri aileleriyle, arkadaşlarıyla ve öğretmenleriyle paylaşmak istediklerini ifade etmiş̧lerdir. Ayrıca öğrencilerin büyük çoğunluğu çocuk üniversitesinde etkinlikleri yaparken hem eğlendiklerini hem de öğrendiklerini belirtmişlerdir. Araştırmada öğrencilerin bu tarz etkinliklerin sürekli yapılmasını istedikleri yönünde görüş belirttikleri de tespit edilmiştir. Öğrencilerin bir kısmı posterlere yönelik açıklamalarında arkadaş ilişkilerini olumlu yönde etkileyen bir süreç yaşadıklarını ifade etmişlerdir. Bu bulguyu, Smith, Steel ve Gidlow (2010)'un yapmış oldukları araştırmada okul kamplarının eğlenceli olduğu ve birlikte zaman geçirildiği için akran ilişkilerini geliştirme ve sosyal açıdan tecrübe kazanma yönünde etkinliklerin yer aldığı yönündeki görüşleri destekler niteliktedir.

$\mathrm{Bu}$ sonuçlardan yola çıkarak, çocuk üniversitesi kapsamında gerçekleştirilen birbirinden farklı ve günlük yaşamla ilişkili etkinliklerin öğrencileri motive edici, ilgilerini ve tutumunu olumlu yönde etkileyebilecek özelliklerinin olmasından ve konulara yönelik merak ve istek uyandırmasından dolayı öğrencilerin olumlu kazanımlarla süreci tamamladıkları ve bu nedenle olumlu görüş bildirdikleri düşünülmektedir. 


\section{INTRODUCTION}

Within the framework of science education, one of the objectives is to teach students how to use scientific process skills so that they can find the ways of solving problems and become science literate. In order to achieve this objective, students are expected to act like a scientist and watch, smell, hear and wonder the nature and natural occurrences and learn how to cope with problems (Türkmen, 2010). Therefore, while teaching science to children particularly the younger ones, they should be enabled to learn by discovering and enjoying themselves and they should be provided with a guidance to reduce their worries and fears and in this way, students are expected to have fun from science (Cho, \& Choi, 2003; Wilson, Cordry, \& Unline, 2004).

In today's world, individuals who establish a relationship between science and everyday life, who transmit this information to their daily lives, who associate their knowledge with science and technology, who are aware of how to learn, who hold critical, reflective and creative thinking skills are called as qualified individuals (Çalışkan, 2013). In the training of science literate individuals who can create links between science and daily life and associate what they have learned with real life, emphasis should be put on informal education as well as formal education (Stocklmayer \& Gilbert, 2003). Informal settings are effective environments that complement students' knowledge and skills, and they provide them with opportunities to make research and experiments and contribute to their inquiry and multi-dimensional thinking skills (Noel-Storr, 2004). That is, education given in informal settings is complementary to classroom education so that students can learn difficult issues better (Emmons, 1997). In these environments, as students are given a lot of time, students can construct their knowledge well (Melber \& Abraham, 1999). In this sense, science camps can be seen as informal settings that are motivating and interesting for students and allow them to discover, make observations, analyze and make inferences from these observations. Though informal education settings have been used in science education for many years, they are now gaining an institutional identity under the name of "Children's University" offering applied education in many disciplines for children. Reasons behind the foundation of Children's universities are to encourage children to think critically and to become curious about science, to introduce them to universities and to raise their awareness of academic culture and to provide them with guidance in their future preferences (EUCU, 2013). Children's universities serving these purposes are rapidly becoming popular in Turkey as they are in the world and through the activities to be conducted in these settings, students will be able to engage in science and scientific activities at early ages.

"Children's Universities Teach about Science to Children at their Early Ages"

Children's universities serve the function of a bridge for children to be introduced to science (Gorard, 2013). In this way, students are believed to experience the pleasure of discovery and learning, they will be able to learn in a different setting from the usual classroom environment by being engaged in activities different from traditional activities so that they can make connections between science and daily life and encounter the entertaining part of learning through individual and group works. Thus, science camps and science schools have gained greater importance to provide students with opportunities to learn in informal settings. The organization called The Scientific and Technological Research Council of Turkey [TÜBİTAK] in Turkey evaluates proposed scientific studies and projects integrating science with the community and decides which one to fund based on some criteria. In scientific and community projects funded by TÜBİTAK, it is expected that participants should recognize scientific phenomena, increase their sense of curiosity, find learning more meaningful and become more willing towards learning and thus, education given in informal settings seems to be of great importance (Buluş Kırıkkaya, Bozkurt \& İmal1, 2011). In this respect, within the context of the activities conducted in the Children's University affiliated to Sinop University located in a city in the north of Turkey, a project was proposed to TÜBİTAK for children to conduct effective scientific activities in informal settings in 2012 and it was found to be worth funding. This project was revised in 2013 and then it was proposed to TÜBITAK once more and again it was found to be worth funding. The name of the first project was "Entertaining Science, Art and Sports School in the Paradise of the North, Sinop" and the name of the second project was "Entertaining Science, Art and Sports School in Sinop Children's University".

In the present study, the purpose is to make the detailed presentation of the activities conducted in the project of "Entertaining Science, Art and Sports School of Sinop Children's University" supported by TÜBİTAK in 2013, to evaluate the students posters designed in relation to the activities conducted and 
to determine the effects of the activities on children's perceptions. In this way though the result of the current study it is expected to contribute to children's universities and the researchers studying in this field around the world. When the related literature is reviewed, it is seen that there are some studies focusing on projects conducted within the framework of science schools (Metin \& Bağc1 Kiliç, 2009; Yardımcı \& Bağcı Kılıç, 2009; Yardımcı, 2009; Buluş Kırıkkaya, Bali, Bozkurt, İşeri \& Vurkaya, 2010; Buluş Kırıkkaya, Bozkurt \& İşeri, 2011; BuluşKırıkkaya, Bozkurt, İşeri, Vurkaya \& Bali, 2011; Buluş Kırıkkaya, Bozkurt \& İmalı, 2011; Cavaş, 2011; Leblebicioğlu, Metin, Yardımcı \& Berkyürek, 2011; Metin \& Leblebicioğlu, 2011; Metin \& Leblebicioğlu, 2012; Cavaş, Cavaş, Muşlu Kaygısız \& Kesercioğlu, 2013). When the number of such studies increases and more opinions of students about the activities they conduct in science schools are revealed, greater contributions will be made to literature and the quality of similar projects will be improved.

\section{METHOD}

In the present study, case study method was employed. The case study method is used to analyze one or few specific cases systematically and in a detailed manner (Yıldırım \& Şimşek, 2008). The case study method involves the in-depth analysis of a single case rather than the analysis of a limited number of variables by following some certain rules. The case study is in fact a means of checking what is happening in an environment, collecting data in a systematic manner, analyzing them and eliciting results (Davey, 1991). On the other hand, the case study is also employed for the evaluation of a program or for in-depth analysis of an occurrence (Marshall \& Rossman, 2006). Yin (2009) classified the case study into four designs based on the researched case and the units of analysis involved in the case. These designs are as follows; Integrated Single Case, Nested Single Case, Integrated Multiple-Case, Nested Multiple-Case.

In the present study, the nested single case design was employed. The nested single case design is defined as a case study when there is a case including more than one case or sub-component nested to each other (Yin, 2009). The only case investigated in the present study is the distribution of the posters designed by the students and their opinions about the posters. The sub-analysis units or components are the distribution of each activity included by the students and their opinions.

\section{Study Group}

The study group consists of 50 students finishing 5th grade and starting 6th grade of elementary schools in the city of Sinop and some of its villages. Criteria set to determine the students to participate in the project of "Entertaining Science, Art and Sports School at Sinop Children's University" on voluntary basis are their having finished fifth grade in 2012-2013 school year and not having participated in such a project before. In order to determine the study group, schools were sent information leaflets, posters including project information and application forms via the directories of National Education in the city and some towns and posters, banners and project information adverts were hung in different places of the city. Students' applications were taken within a pre-set dates and the participants were determined through simple random sampling method among all the applications.

Students' gender, type of the school they attend, education levels of their mothers and fathers and occupational status of their mothers and fathers were set to be their demographic features. Out of the participants, 27 are females and 23 are males. Of the participants, 49 are from state schools and 1 of them is from a private school. The education levels of the mothers are as follows: elementary school graduates $(f=26)$, university graduates $(f=13)$, master's or $P h D$ graduates $(f=6)$ and high school graduates $(\mathrm{f}=5)$ and the education levels of the fathers are as follows: elementary school graduates $(\mathrm{f}=18)$, university graduates, master's or $\mathrm{PhD}$ graduates $(\mathrm{f}=9)$ and high school graduates $(\mathrm{f}=5)$.

\section{Data Collection Instrument and Process}

The data source of the current study includes posters prepared by the students on the last day of the project within the context of an activity called "Poster competition: Our imagination is at work" and the explanations made by the students about their posters. Within this activity, the students were asked to think about the activities they had performed throughout the project and then assume that they had to explain the project to someone who did not know anything about the project and following these reflections, they were asked to prepare their posters. In this activity, each student prepared their posters 
individually and they were given 60 minutes to do this. Then the students' posters were collected and underwent a preliminary examination and after that, they were displayed on boards. The students were given 10 minutes to examine each poster in the exhibition. Following this, each student explained what they did in their own posters, what they intended to explain through their drawings and what types of messages they intended to convey with their writings on the posters and this process was video recorded. While a student was making his/her explanations, his/her peers listened to him/her. After their presentation of their posters, the students' explained their feelings and thoughts about the science school and the activities they conducted in this school. In this way, all the participants were able to explain their thoughts and opinions and the application was finished. The posters were divided into some certain categories (the most affectionate poster, the most environmentalist poster, the most colorful poster etc.) by 5 persons monitoring the activities throughout the project. The students' posters and explanations about the posters were analyzed together and in this way, the collected data were evaluated. A poster is a two-dimensional graph designed to introduce a project to a visitor who has no prior information about the project (Yaman \& Karamustafaoğlu, 2005). As posters are an important means of exchanging information between the presenter and the presented (Çepni \& Çil, 2009), they are regarded as an important source of information in the current study. The use of drawing in guiding the interview facilitates the children to talk about what they fell comfortable revealing to the researcher (Ogina, 2012). Many researchers indicated that children express themselves more comfortable by drawing (Young \& Barrett, 2001; Backett-Milburn \& McKie, 1999; Yuen, 2004; Driessnack, 2006). In this regard, poster technique was preferred in the current study as it enabled the participants of the study to illustrate their feelings and opinions about the science, art and sports school and activities performed in this school. Another data source of the current study which employed the case study method is semi-structured interviews used to elicit the students' explanations about their posters. In semi-structured interviews, all of the questions are used either flexibly or they are mixed and less structured (Merriam, 2009). In the case study method, many techniques such as observation, document analysis, survey, interview and Delphi techniques are used (Dooley, 2002).

\section{Activities conducted in the Science, Art and Sports School}

In the TÜBİTAK funded project "Entertaining Science, Art and Sports School in Sinop Children's University" carried out by Sinop University Children's University, 29 people were recruited and these people were 1 coordinator, 5 experts, 12 instructors, 10 counselors and 1 unit secretary. Within the framework of the project lasting for 5 days, 22 different science, art and sports activities were conducted. Great attention was paid for these activities to be interesting for students, to be related to daily life and to be carried out with easily available materials. In order to provide some insights into the nature of the activities conducted within the project, some sample activities are given below:

"Entertaining-Dangerous Sides of Chemistry: Foaming Magic and Match of the Chemistry": In this activity, the aim is to make students analyze reactions, reaction speed, factors affecting the speed of a reaction and the effect of the catalyst on the speed of a reaction, to raise their awareness of both interesting and dangerous sides of chemistry by means of observations of the reaction process and outcomes of this process and to make them aware of the results that may stem from unconscious use of chemical materials. In the foaming magic experiment, a mixture was prepared with liquid detergent, food dye and hydrogen peroxide and then with the addition of potassium iodide, foaming colorful mixture was observed. Within the framework of the match of chemistry experiment, concentrated sulphuric acid was dropped into the mixture of potassium chlorate and sugar and then flames and smoke were observed.

"Stone Painting: Let's Imagine, Select our Stone and Paint it": The purpose of this activity is to make students reflect their creative and aesthetic views on different materials, to make them understand visual perception and conduct visual thinking. Therefore, students were allowed to paint stones however they wished and then assigned them some meanings based on analogies.

"Agriculture-based Science Education Applications: My Kite is on the Sky":The purpose of this activity is to make students create links between science subjects and daily life by means of design-based science teaching. Through this activity, the students were provided with opportunities to use scientific information within entertaining activities. In this connection, each student made kites under the guidance of counselors and learned the basic physical information about flying. 
"Sky Observation Festival": Within this activity, the main goal was to make students observe the sky with both naked eyes and telescope. In order to facilitate these observations, the students were given sky map of the related moon. Different star clusters were introduced to the students and they were informed how these star clusters had been named years ago. Then, the telescope was arranged to observe the planets of Venus and Saturn and then observations of these planets were made. The objectives of this activity were to impart basic information about astronomy to the students and inform them about the features of planets and star clusters.

"Let's Build Our Ship Model on Our Own: Little Masters are at Work":As it is a natural port city located on the coastline of Black Sea, Sinop is famous for model ship production. The objective of this activity was to inform the students about how to make a ship model and a trip was organized for students to visit a ship model production workshop. Then, each student produced his/her own ship model and painted it. "Enjoyable Warm-up-Educational Game (Riziko)":Within the framework of this activity, the main objectives were to instill the habit of physical activity through sports activities in the students, raise their awareness in the field of physical-kinesthetic intelligence and in this way, to enhance self-confidence, desire to achieve and cope with difficulties, self-expression and thinking skills, to teach them the meaning of winning and losing, to improve the sense of competition within the emotions of sharing and cooperation and to make the students enjoy, relax and have a good time by using their physical, cognitive, emotional and social motor skills.

"A Bit Art in Life: Marbling Art": The purpose of this activity was to make the students express their artistic, aesthetic and creative sides on various materials. In this activity, the students experienced the harmony of colors and created a work of art with their brushstrokes.

"Making a Flying Balloon in the Field":Within the framework of this activity, the students were asked to write how to design a flying balloon from the given materials by means of Prediction-ObservationExplanation (POE) method. For this purpose, information about the movement of heated gases was used and theoretical explanations were made. By giving information about the working principle of a flying balloon and then what kind of balloon could be designed with the given materials was discussed. The activity was performed individually and each student designed a flying balloon. At the end of the activity, the students were asked to note down their observations and in this way, they were allowed to indicate whether their prior opinions changed or not

"We Have Learned the Types of Soil and Root: Let's Plant Flowers!":In this activity, the students were shown how to prepare a mixture of soil + turf + perlite+ fertilizer. Then, this mixture was put into plant pots and flowers were planted. At the end of the activity, the students wrote the names they gave to their flowers on their plant pots.

\section{Data Analysis}

The data collected in the present study, were evaluated in two different ways. In the analysis of the collected data, NVivo 8 Qualitative Data Analysis Program was employed and some of the data underwent descriptive analysis and some underwent content analysis. On the first stage of the evaluation, the activities loved by the students were determined from their posters. Each activity mentioned by the students was set as a theme and in this regard, descriptive analysis was run. Descriptive analysis is a type of analysis in which the collected data are summarized and interpreted according to previously set themes and direct quotations are frequently used to illustrate participants' opinions strikingly (Y1ldirım $\&$ Şimşek, 2008). The codes to be subsumed under each theme were determined based on the students' opinions. The second stage of the evaluation includes the analysis of the students' opinions about their posters. At the end of the science, art and sports school project, the students' opinions about the project and its activities were explored and a coding key was constructed and the data were analyzed through "content analysis". In the construction of the coding key, NVivo8 qualitative data analysis program was used. Conducting the analyses by using a program improves the reliability of a study (Kuş, 2007). While constructing the coding key, first, the students' positive and negative opinions about the activities were determined. After that, common themes were created for similar responses of the students based on their positive and negative opinions. During the construction of the themes, the students' common statements were considered. In order to elicit the common themes, responses given to each question were continuously compared. The themes and codes constructed by two researchers were evaluated by the researchers and they were compared to each other and final forms of the themes and codes were given. The reliability of the data analyses was calculated with [(Agreement of opinions) / (Agreement of 
opinions + Disagreement of opinions)] x 100 formula (Miles \& Huberman, 1994). The average reliability between the researchers performing coding was found to be $89 \%$.

\section{FINDINGS}

\section{Findings related to the Activities Included in the Posters of the Students}

Frequency values related to activities included in the posters of the students within the framework of the activity "Poster Competition: Our Imagination is at Work!" and related to how many posters include each activity are presented in Figure 1 from the most mentioned activity to the least mentioned one in the posters.

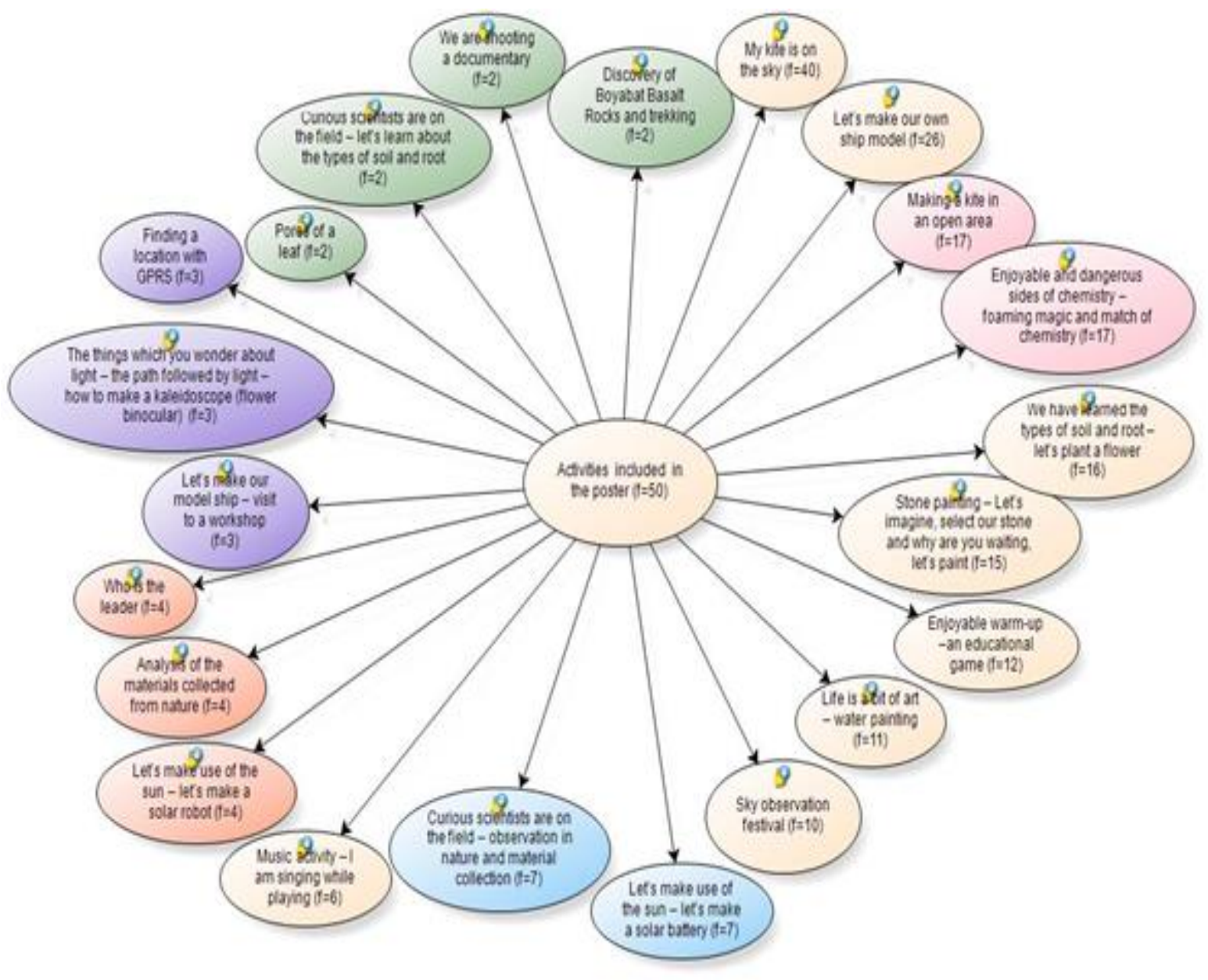

Figure 1. The most mentioned activity to the least mentioned one in the posters

As can be seen in Figure 1, the students illustrated all the activities performed in the science school at varying frequencies. The frequencies of the activities depicted in the students' posters are as follows: My Kite is On the Sky ( $\mathrm{f}=40)$, Let's Build Our Ship Model on Our Own ( $\mathrm{f}=26)$, Making a Flying Balloon in the Field $\mathrm{f}=17)$, Enjoyable and Dangerous Sides of Chemistry: Foaming Magic and The Match of Chemistry ( $\mathrm{f}=17)$, We Have Learned the Types of Soils and Root: Let's Plant Flowers! ( $\mathrm{f}=16)$, Stone Painting: Let's Imagine, Select our Stones and Why are you Waiting, Let's Paint! ( $\mathrm{f}=15)$, Enjoyable Warm-up-Educational Game ( Riziko) ( $\mathrm{f}=12)$, A Little Art in Life: Marbling Art ( $\mathrm{f}=11)$, Sky Observation Festival (f=10), Exploit the Sun: Let's Produce a Solar Battery ( $\mathrm{f}=7)$, Curious Scientists are on the Field: Observation and Material Collection in Nature ( $\mathrm{f}=7)$, Musical Activity: Let's Sing while Playing Instruments ( $\mathrm{f}=6)$, Exploit the Sun: Let's Build a Solar Robot ( $\mathrm{f}=4)$, Who is the Leader? $(\mathrm{f}=4)$, Investigation of the Materials Collected from Nature in a Laboratory Setting $(\mathrm{f}=4)$, Locating with GPRS $(\mathrm{f}=3)$, The Things You Wonder about the Subject of Light, What Type of Route is Followed by Light? 
How Kaleidoscope is Produced? (f=3), Let's Build Our Ship Model on our Own: Workshop Trip (f=3), Discovery and Trekking in Boyabat Basalt Rocks $(\mathrm{f}=2)$, Curious Scientists are in the Field: Let's Learn the Types of Soil and Root ( $\mathrm{f}=2)$, We are Shooting a Documentary $(\mathrm{f}=2)$, Pores of a leaf $(\mathrm{f}=2)$ and Poster Competition and Our Imagination is at Work $(\mathrm{f}=1)$.

All of the students participating in the activity stated positive opinions about science, art and sports school in their explanations ( $\mathrm{f}=50)$ and reflected these opinions in their posters. It was determined that activities most commonly depicted in the students' posters are the activities they liked, enjoyed and were impressed. In addition, high majority of the students $(\mathrm{f}=48)$ stated that they liked the activities conducted in the Children's university very much, some of them $(\mathrm{f}=21)$ stated that inclusion of artistic and sports activities made the process more enjoyable and majority of them ( $\mathrm{f}=34)$ encountered some of the activities for the first time, they learned by doing and they wanted to share what they had learned with their peers, parents and teachers. Some of the posters prepared (Picture1: S1's poster, Picture 2: S7's Poster, Picture 3: S13's Poster ... similarity... Picture 13:S39's poster) by the students and their related explanations are given below:

Figure 1. S1's poster

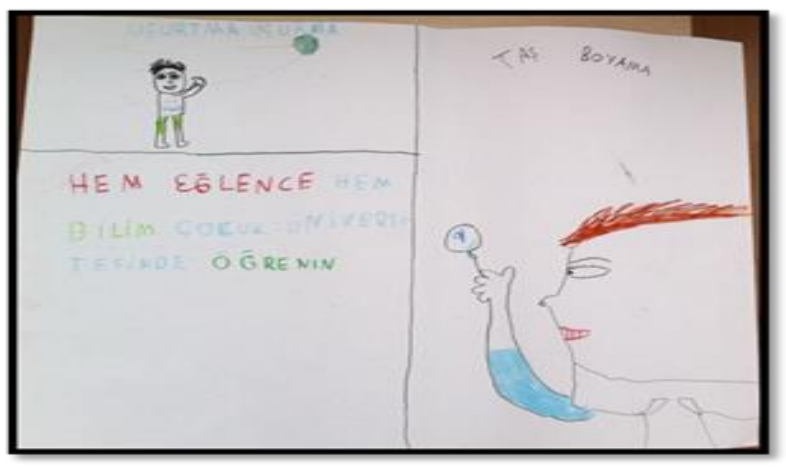

"I wanted to illustrate the activities I have done for a whole week by means of drawings. I wanted to explain a lot in my poster so that a person who does not know anything about this project can understand it. I also wrote a slogan "Both fun and science; learn in the Children's university". My current thoughts are very different from my thoughts I had when I came here first. Here, we both had fun and learned and we made many friends. We conducted many experiments in groups and we made decisions together for some activities. I am happy as I came here, I wish it were every year." S1



Figure 2. S7's poster

"I wanted to explain how much I enjoyed myself and learned in the Children's university. Thus, I painted the activities I liked the most here. I also illustrated other activities in my poster, too. I wanted to introduce the project in this way. I even wrote a slogan: Music, science, fun, all of them are in the Children's university." S7 


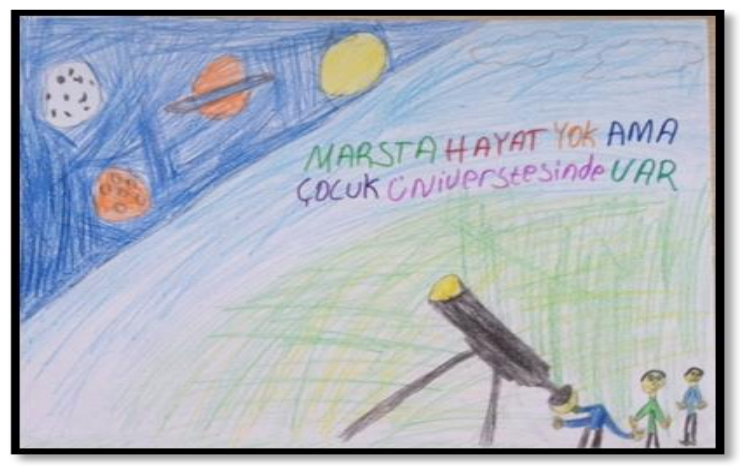

Figure 3. S13's poster

"While drawing my picture, I thought about what I would like to explain. Then I illustrated my thoughts through drawings. I had great fun and learned many things while conducting activities. I wanted to illustrate all the activities but as it was not possible I only illustrated the ones I most clearly remember. I learned new things in the Children's university. I have never watched the sky with a telescope before it was really different and enjoyable." S13

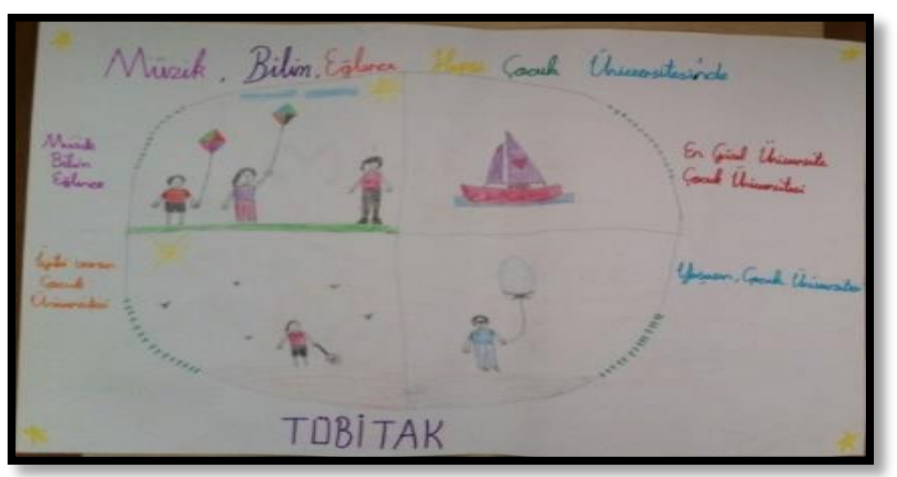

Figure 4. S17's poster

"When I came here first, I thought that I would be really bored because I did not know anyone. However, it was not as I had expected, it was a very different experience for me. I put the activities I liked the best in the Children's university in my poster. I illustrated the experiments we had done, the model ship we had painted, solar battery and robot we had made. We liked science and sports so much. We liked Sinop University too much." S17

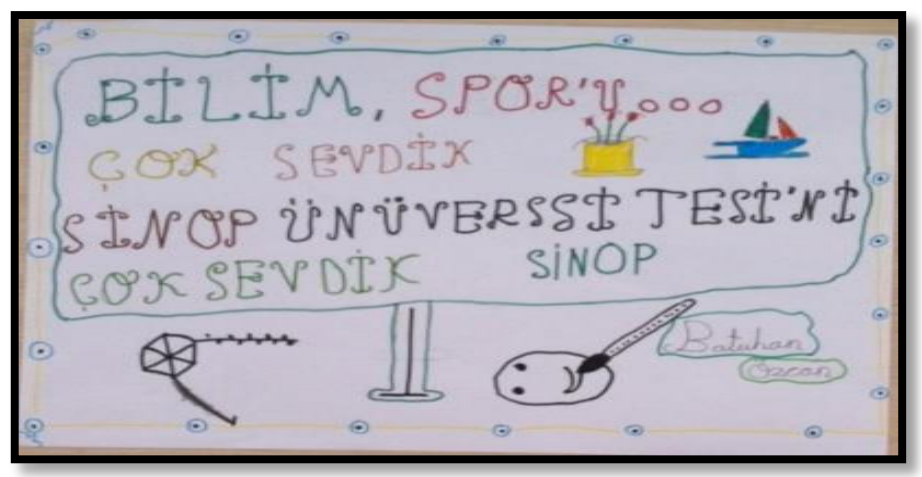

Figure 5. S6's poster

"I wanted to explain the Children's university with slogans in my poster. I wanted to illustrate the enjoyable activities we performed. Enjoy yourselves, learn and develop improve yourself. By writing more than one slogan, I tried to show the importance of the Children's university for me. I want all 
children to participate in these activities. It was both entertaining and instructive environment. I also liked all the teachers, they taught me many valuable things, thanks." S6



Figure 6. S32's poster

"In my poster, I illustrated my days spent in a week. We all flew kites. This was the most enjoyable activity. I had great fun and good score. I have my own kite now. We both made the kite and flew it with our instructor." S32



Figure 7. S15's poster

"I tried to explain what we had done in my poster. I illustrated how we built a boat. I particularly liked the activity of stone painting. I also like kite activity very much but by accident, my kite got stuck in a tree and my friend helped me. I told my parents about the activities I had done here, I will tell all my friends when the school opens. I will tell them that the Children's university is full of interesting and entertaining activities." S15

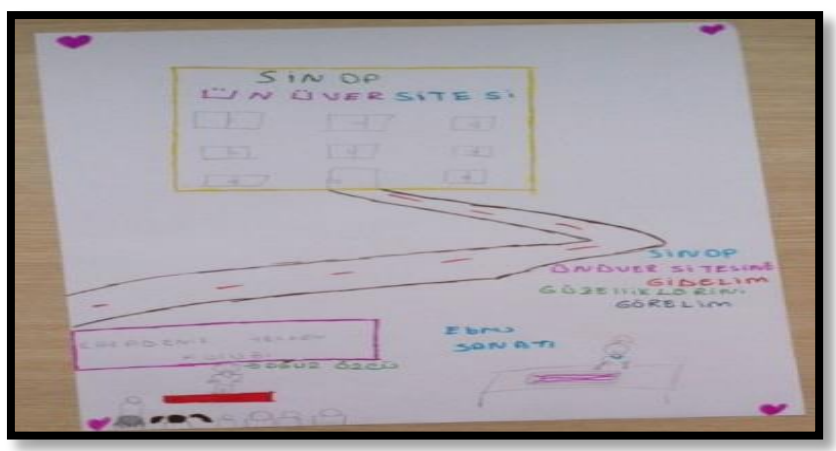

Figure 8. S18's poster

"I came to the Children's university as my parents wanted but then I felt quite happy to be here. When I came here first, I did not know what kind of place it was and what I would do; thus, I was worried. I briefly illustrated the activities we had done here. I particularly enjoyed painting a boat, planting flowers, collecting insects and flying kites. I spent my days having fun. While I was having fun, I also learned 
many things. I wish we had such activities at school. I am happy to have come here. I wish I would stay for another week." S18



Figure 9. S9's poster

"I illustrated four activities I liked in my poster. I liked the activity of "my kite is on the sky" the most. We both worked together and had great fun. I also illustrated laboratory activities, boat painting and material collection activities. I did not expect the teachers to be so warm to us, but they were really good. I think this is a wonderful school. I want to come every year." S9

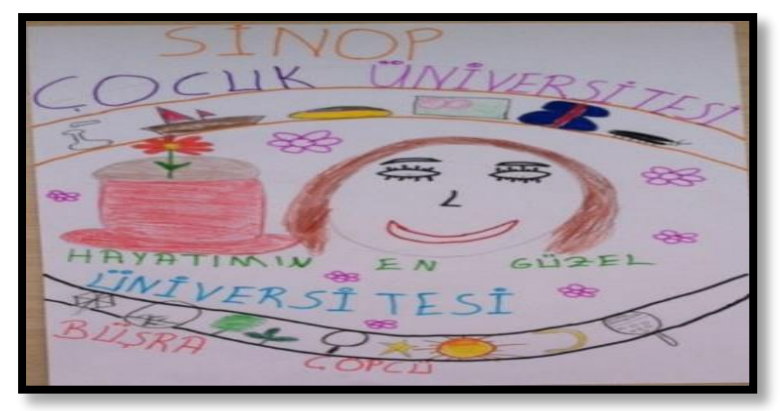

Figure 10. S23's poster

"I was thinking quite different before coming to the Children's university. I am happy to have been here and now I am sad to leave. We made a lot of activities, in a laboratory, nature and a workshop this was the most beautiful, enjoyable and instructive week of my life. Here, what I wanted to draw is a child having many questions marks before coming here and finding answers after coming. Learn through activities." S23

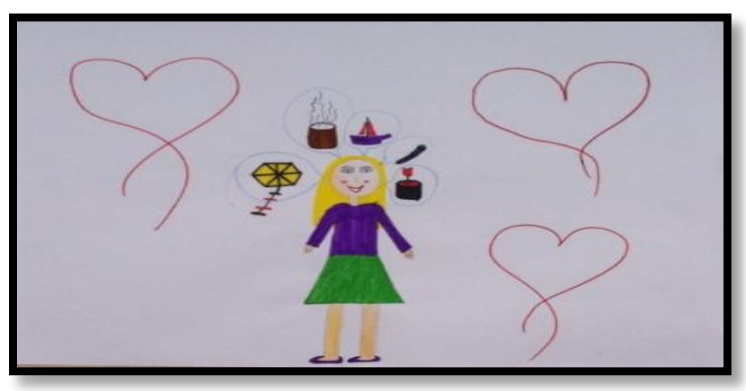

Figure 11. S11's poster

"I illustrated the activity I liked the most in my poster. It was wonderful, we conducted different experiments outside the school, I liked this very much, I recommend every child to come here. I drew happy children in my poster of the Children's university. One of these children is me. I made new friends here, at the beginning; I thought differently, I even thought that I might get bored but it was very enjoyable and instructive, so I am very happy. I will tell my teachers and friends all the activities I did here." S11 


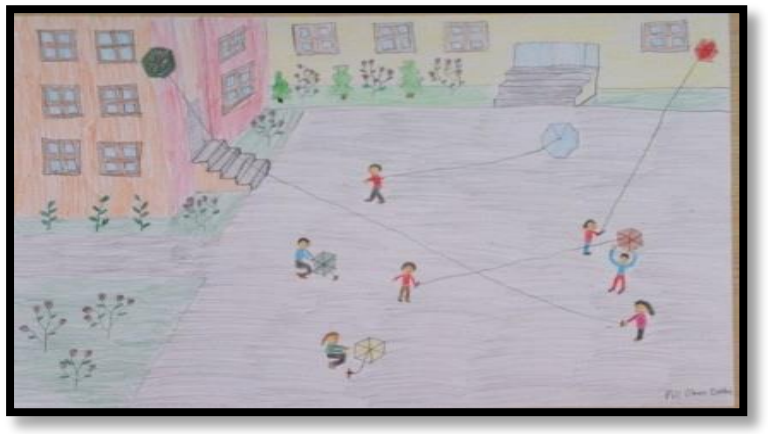

Figure 12. S39's poster

"I illustrated the activities I liked the best in my poster. Flower binocular, ship model, sky observation, my kite is on the sky, foaming magic, I liked these activities too much. I spent wonderful time in science school and had great fun. I was expecting to conduct experiments and we did in the Children's university, I liked it very much. The hearts I drew show how happy I am here, I will miss the Children's university. I hope will be able to come again." S39

\section{DISCUSSION}

As a result of the students' posters and their explanations related to their posters within the framework of the activity "The Poster Competition: Our Imagination is at Work" done on the last day of the project "Entertaining Science, Art and Sports School at Sinop Children's University" organized by Sinop University Children's University with the support of TÜBİTAK, the data of the present study were collected through semi-structured interviews and it was found that the most frequently recurring themes in the posters are as follows: Entertaining and Dangerous Sides of Chemistry: Foaming Magic and the Match of Chemistry; Stone Painting: Let's Imagine, Select our Stone and What Are You Waiting For, Let's Paint!; "Design-based Science Applications: My Kite is on the Sky" "Sky Observation Festival", Let's Build our Ship Model Ourselves: Little Masters are at Work, Enjoyable Warm-up and Game (Riziko) and A Bit Art in Life: Marbling Art. It seems that the student illustrated the activities in which they participated actively in their posters. Moreover, the students painted the activities they liked, enjoyed and were impressed by in their posters. Majority of the students stated that they liked all the activities they had conducted in the Children's university, inclusion of artistic and sports activities together with science activities motivated them more, they encountered some activities for the first time, they felt that they learned by doing and they wanted to share the information they had learned with the parents, friends and teachers. This finding is supported by the findings reported by Buluş Kırıkkaya, et al. 2010; Buluş Kırıkkaya, et al. 2011; Buluş Kırıkkaya, et al. 2011). This finding indicates that students can also learn outside the school when proper learning environments are provided. Though the students found the process motivating and instructive, it is not clear how much they learned during the process. However, as stated by Yardımcı \& Bağcı Kılıç (2009), even if they are short, science camps structured in a similar manner to the one in the present study can leave long-lasting effects in students' minds.

High majority of the teachers stated that they both had fun and learned while conducting the activities in the Children's university. In literature, there is much research reporting that science camps prepare enjoyable and instructive settings for informal learning of students and students feel very happy while doing the activities (Verma, 2007; Metin \& Bağc1 Kılıı̧, 2009; Yardımcı \& Bağc1 Kılıç, 2009; Buluş Kırıkkaya, et al. 2010; Buluş Kırıkkaya, et al. 2011; Buluş Kırıkkaya, et al. 2011).

It was also found that the students also stated that they would like to conduct similar activities in other times. This shows that though the activities lasted for the whole day, the students did not get bored. Furthermore, the students view the incorporation of artistic and sports activities into the program as something positive. The variety of the activities makes positive contribution to students' development in different skill areas (Gerber, Cavallo \& Marek, 2001; Tatar \& Tekbıyı, 2012).

Some of the students stated in their explanations related to their posters that they experienced a positive process in their friendship relationships. This finding concurs with the findings reported by Smith, Steel and Gidlow (2010). Yardimc (2009) also stated that the students constructed good friendship 
relationships in the camp, though it was a short-time camp. This is important for students to enhance their cognitive, affective and psychomotor skills (Lakin, 2006; Tekbıyı, Şeyihoğlu, Sezen Vekli \& Birinci Konur, 2013).

In light of these findings, it can be argued that the various and daily life-related activities conducted in the science school are motivating, interesting and positively affecting students' attitudes; thus, students completed the process with positive gains and therefore, they stated positive opinions about the process. Indeed, teaching of science subjects by means of real-life examples and students' learning the subjects by touching, observing and researching materials make the information permanent and meaningful (Tatar \& Tekbıyık, 2012). In this connection, some suggestions can be made for such informal learning environments to be more comprehensive and common.

\section{CONCLUSION}

Children's university science-community projects can be used to introduce science to students, make them aware of the importance of researching, questioning and wondering and raise their awareness of nature and encourage them to learn by means of science, art and sports activities. When the fact that the process helps students to acquire some cognitive, affective and psychomotor skills is considered, activity programs in Children's universities should be offered to students from every age group so that they can become more common. Activities conducted within the framework of Children's universities require easily available materials and are connected to daily life; hence, they can be used at schools.

\section{REFERENCES}

Bogdan, R. C. \& Biklen, S. K. (2007). Qualitative research for education, an introduction to theories and methods (5th Edition). USA: Pearson Educationi Inc.

Buluş Kırıkkaya,E., Bali, G., Bozkurt, E., İşeri, Ş. \& Vurkaya, G., (2010). Entertaining science summer school activities for primary pupils. XIV. International Organization for Science and Technology Education (IOESTE) Symposium, 13-18 June, Bled, Slovenia.

Buluş Kırıkkaya E., Bozkurt, E. \& İmalı, B., (2011). An example of a learning environment: TÜBİTAK supported science summer school for primary pupils. International Congress On Curriculum and Instruction, 5-8 October, Eskişehir.

Buluş Kırıkkaya, E., Bozkurt, E., İşeri, Ş., Vurkaya, G. \& Bali, G. (2011). TÜBİTAK supported science summer school for primary school students: happinence of learning by exploring and enjoying. 3rd World Conference on Educational Sciences (WCES), 3-7 February, Ístanbul, Turkey.

Buluş Kırıkkaya, E., Bozkurt, E. \& İşeri, Ş., (2011). Effect of TÜBİTAK supported primary school students science summer school on students image of scientist. Mediterranean Journal of Educational Research, 9 , $61-75$.

Cavaş, B. (2011). Outdoor education in natural life park: an experience from Turkey. Science Education International, 22(2), 152-160.

Cavaş, B., Cavaş, P., Muşlu Kaygısız, G. \& Kesercioğlu, T. (2013). Outdoor education in Izmir natural life park. IOSTE Eurasian Regional Symposium \& Brojerage event Horizon 2020, 30 October-1 November, Antalya. Turkey.

Cho, H., Kim, J. \& Choi, D. H. (2003), Early childhood teachers' attitudes towards science teaching: a scale validation study. Educational Research Quarterly, 27(2), 33-42.

Çalışkan, İ. (2013). A study about preservice science teachers' educational psychology approaches and planning processes. Hacettepe University Journal of Education, Özel sayı (1), 68-83.

Çepni, S. \& Çil, E. (2009). Fen ve teknoloji programı ilköğretim birinci ve ikinci kademe öğretmen el kitabı (Science and technology program for first and second grade elementary school teacher's manuals). Ankara: Pegem A Yayıncilik.

Davey, L. (1991). The application of case study evaluations. Practical Assessment Research \& Evaluation, 2(9). Retrieved from. http://Pareonline.net/getvn.asp?v=2\&n=9 on 8.5.2014.

Dooley, L. M. (2002). Case study research and theory building. Advances in Developing Human Resources, 4(3), 335-354.

Emmons, K. M., (1997). Perceptions of the environment while exploring the outdoors: A case study in Belize. Environmental Education Research 3(3), 327-344.

EUCU (European Children's Universities Network) (2013) Retrieved from at: http://eucu.net/charter on 8.11.2013. 
Fontana, A., \& Frey, J. H. (2005). The interview: From neutral stance to political involvement. In N. K. Denzin \& Y. S. Lincoln (Eds.). The Sagehandbook of qualitative research(2nd ed., pp. 695-727). Thousand Oaks, CA: Sage.

Melber, L. M. \& Abraham, L. M., (1999). Beyond the classroom: Linking with informal education. Science Activities, 36(1), 3-4.

Gerber, B.L., Cavallo, A.M.L. \& Marek, E.A. (2001). Relationships among informal learning environments, teaching procedures and scientific reasoning ability. International Journal of Science Education, 23(5), 535- 549.

Glesne, C. (2013). Becoming Qualitative Researchers: An Introduction "Nitel araştırmaya giriş (A. Ersoy, trans.)." Ankara: Anı Publishing.

Gorard, S. (2013). Childrens university. Education Endowment Foundation. Retrived from http://educationendowmentfoundation.org.uk/uploads/pdf/Cabinet_Office_Childrens_University.pdf on 5.01.2012.

Kuş, E. (2007). NVivo 8 ile nitel araştırma projeleri. "Qualitative research projects with NVivo 8”. Ankara: Anı Publishing.

Lakin, L. (2006). Science beyond the classroom. Journal of Biological Education, 40(2), 88-90.

Leblebicioğlu, G., Metin, D., Yardımc1, E. \& Berkyürek, İ. (2011). Teaching the nature of science in the nature: a summer science camp. Elementary Education Online, 10(3), 1037-1055.

Marshall, C. \& Rossman, G. B. (2006). Designing qualitative research (4th Edition). USA: Sage Publications.

Merriam, S. (2009). Qualitative research: A guide to design and implementation. San Francisco, CA: Jossey-Bass.

Metin,D. \& Bağcıkılıç, G. (2009). The effect of the science camp program on children's views of he tentative nature of science. Science Education Research Association Conference, İstanbul, Turkey.

Metin,D. \& Leblebicioğlu, G.(2011). How did a science camp affect children's conceptions of science? AsiaPacific Forum on Science Learning and Teaching, 12(1), 1-29.

Metin,D. \& Leblebicioğlu, G. (2012). The effect of the science camp program on children's views of he tentative nature of science. Journal of Studies in Education, 2(1), 164-183.

Miles, M. B. \& Huberman, A. M. (1994). Qualitative data analysis. London:Sage Publication.

Noel-Storr, J., (2004). The role of immersive informal science programs. Retrived from http://arxiv.org/ftp/physics/papers/0403/0403144.pdf on 21. 10. 2013.

Smith, E.F., Steel, G. \& Gidlow, B. (2010). The temporary community: student experiences of school based outdoor education programmes. Journal of Experiential Education, 33(2), 136-150.

Sönmez, V. \& Alacapınar, F.G. (2011). Örneklendirilmiş bilimsel araştırma yöntemleri. "Exemplified Research Methods" Ankara: Anı Publishing.

Stocklmayer, S. \& Gilbert, J., (2003). Informal chemical education in international handbook of science education. Part one. Netherlands: By Kluwer Academic Publishers.

Tatar, N. \& Bağrıyanık, K.E. (2012). Opinions of science and technology teachers about outdoor education. Elementary Online, 11(4), 883-896.

Tekbıyık, A., Şeyihoğlu, A. \& Sezen Vekli, G. \& Birinci Konur, K. (2013). Influence of a science camp based on active learning on students. The Journal of Academic Social Science Studies, 6(1), 1383-1406.

Türkmen, H. (2010). (sınıf-dışı) fen bilgisi eğitimine tarihsel bakış ve eğitimimize entegrasyonu. "Historical perspective of informal science education and training to our integration." Çukurova Universty Journal of Educational Faculty, 3(39), 46-59.

Yaman, S. \& Karamustafaoğlu, S. (2005). Öğretmen adaylarının kimya dersine yönelik tutumları ve mantıksal düşünme becerileri üzerine bir araştırma, "A survey of chemistry lesson attitudes and logical thinking skills to teachers candidates". XIV. Ulusal Ĕ̈itim Bilimleri Kongresi, 2, 467-472, Denizli.

Yardımcı, E. \& Bağcı Kılıç, G., (2009). Effect of nature-based educatin on a camp on children's attitudes towar environment and their ideas about human-nature interaction. Science Education Research Association 2009 Conference, Istanbul, Turkey.

Yardımcı, E., (2009). Yaz bilim kampında yapılan etkinlik temelli doğa ĕgitiminin ilköğretim 4 ve 5.sınıftaki çocukların doğa algılarına etkisi. "The effect of activity natüre education at a summer science camp on 4th and 5th graders conceptions of the nature (Yayımlanmamış Yüksek Lisans Tezi). Abant İzzet Baysal University, Institute of Social Science, Bolu, Turkey.

Yıldırım, A. \& Şimşek, H., (2008). Sosyal bilimlerde nitel araştırma yöntemleri (7. Press). Qualitative Research Methods in Social Science. Ankara: Seçkin Publishing.

Yin R. K. (2009). Case study research: Design and methods (4th ed.). California: SAGE Pub. Thousand Oaks.

Verma, H. C. (2007). Children's science training camp., Retrived from http://www.iitk.ac.in/infocell/iitk/cstprogramme.pdf on 24.05.2014.

Wilson, J. D, Cordry, S. \& Unline, C. (2004), Science fairs: promoting positive attitudes towards science from students participation. Student Journal, 38 (1). 